\title{
Single Exposure of Human Oral Mucosa Fibroblasts to Ultraviolet B Radiation Reduces Proliferation and Induces COX-2 Expression and Activation
}

\author{
Boza $\mathrm{Y}^{1,2}$, Yefi $\mathrm{R}^{1}$, Rudolph MI', Smith $\mathrm{PC}^{3}$, Oberyszyn $\mathrm{TM}^{4}$, Tober $\mathrm{KL}^{4}$, Rojas $\mathrm{IG}^{1}$
}

\begin{abstract}
The lip vermillion constitutes a transition tissue, between oral mucosa and skin, where oral mucosal cells from epithelial and connective tissue compartments are exposed to ultraviolet (UV) sunlight. Fibroblasts are abundant resident cells of the connective tissue which are key regulators of extracellular matrix composition, as well as, epithelial and endothelial cell function. UVB light, an inherent component of sunlight, causes several alterations in skin fibroblasts, including premature senescence and increased cyclooxygenase (COX)-2 expression. To assess if UVB irradiation had similar effects on fibroblasts derived from human oral mucosa (HOM), primary cultures of HOM fibroblasts were irradiated with a single dose of $30 \mathrm{or} 60 \mathrm{~mJ} / \mathrm{cm}^{2}$ of UVB light or shamirradiated. Fibroblast proliferation was assessed from 3 to $48 \mathrm{hrs}$ after UVB-irradiation utilizing $\left[{ }^{3} \mathrm{H}\right]$-thymidine incorporation and MTT assays. In addition, COX-2 mRNA expression was detected by RT-PCR, and PGE ${ }_{2}$ production was assessed using enzyme immunoassay from 0.5 to 24 hrs after UVBirradiation. The results showed a significant decrease in proliferation of UVB-irradiated HOM fibroblasts as compared to controls as measured by both $\left[{ }^{3} \mathrm{H}\right]$-thymidine incorporation and MTT assays $(\mathrm{p}<0.001)$. HOM fibroblasts had increased COX-2 mRNA expression at 0.5 and 12 hrs after irradiation, and $\mathrm{PGE}_{2}$ production was elevated at 12 and 24 hrs post-irradiation as compared to controls $(p<0.05)$. The results showed an inhibitory effect of a single dose of UVB irradiation on HOM fibroblast proliferation with an increase in COX-2 expression and activation. Therefore, photodamaged fibroblasts may play and important role in the pathogenesis of UV-induced lesions of the lip.
\end{abstract}

Rev. Clin. Periodoncia Implantol. Rehabil. Oral Vol. 3(3); 123-127, 2010.

Key words: Oral fibroblasts, UVB, COX-2, proliferation, $\mathrm{PGE}_{2}$.

\section{INTRODUCTION}

The lip vermillion constitutes a transition tissue, between oral mucosa and skin, where oral mucosal cells (e.g., keratinocytes, fibroblasts, mast cells and endothelial cells), are exposed to different types of environmental insults including ultraviolet (UV) sunlight ${ }^{(1)}$. Chronic exposure of the lip vermillion to sunlight results in several alterations at the epithelial and connective tissue compartments which are similar to those described in photodamaged $\mathrm{skin}^{(2-4)}$. These alterations include hyperplasia and overexpression of p53 and cyclooxygenase (COX)-2 at the epithelium, and elastosis and inflammatory infiltration at the lamina propria $^{(2,5-7)}$

UVB (290-320) light is an inherent component of sunlight. Although it affects predominantly the epidermis of the skin, UVB light also penetrates up to the reticular dermis, which is mainly composed of fibroblasts and extracellular matrix $(\mathrm{ECM})^{(8,9)}$. Similar to skin, it is highly probable that the lamina propria of the lip is reached by UVB light, since oral mucosa has a higher capacity for UVB light absorption than other tissues ${ }^{(10)}$. In addition, differences in ECM production and matrix metalloproteinase (MMP) gene expression have been described between skin and oral mucosa fibroblasts, suggesting a different fibroblast phenotype depending upon the tissue of residence ${ }^{(11,12)}$.

Studies analyzing the effects of UVB light on cultured skin fibroblasts showed that repeated exposure to subcytotoxic doses of UVB induces premature senescence ${ }^{(13)}$, resulting in a sharp decrease in cell proliferation $^{(14)}$. In addition, UVB exposure of skin fibroblasts stimulates the expression of several cell cycle regulatory genes, such as p53, as well as, pro-inflammatory genes, such as COX-2 ${ }^{(14,15)}$. UVB-induced COX-2 expression increases the production of prostaglandin $E_{2}\left(P_{G} E_{2}\right)$ by catalyzing the rate limiting step in the conversion of arachidonic acid into $\mathrm{PGs}^{(3)}$. Increased $\mathrm{PGE}_{2}$ production has been implicated in skin photodamage and photocarcinogenesis, since it stimulates generation of reactive oxygen species (ROS), oxidative DNA damage, keratinocyte proliferation and angiogenesis $\mathbf{s}^{(3,16,17)}$.
Very few studies have analyzed the effects of UV radiation on oral mucosa fibroblast function. Williams et al. (1992) found that human gingival fibroblasts irradiated with UVA light had a significant decrease in proliferation ${ }^{(18)}$, and Lim et al. (2008) found that UVC radiation caused gingival fibroblast apoptosis ${ }^{(19)}$. It is known that several factors induce COX-2 expression in oral fibroblasts, including nicotine, areca nut extracts (arecoline), pro-inflammatory cytokines and LPS ${ }^{(20-23)}$. However, the effects of UVB radiation on COX-2 expression and activation in oral mucosa fibroblasts are unknown. Therefore, this study was aimed at characterizing the effects of a single exposure to subcytotoxic doses of UVB light on proliferation, COX-2 expression and $\mathrm{PGE}_{2}$ production by primary fibroblast cultures established from human oral mucosa (HOM) explants.

\section{MATERIAL AND METHODS}

\section{Isolation and Culture of Oral Mucosa Fibroblasts}

Primary fibroblast cultures from human oral mucosa (HOM) were isolated by the explant method as previously described ${ }^{(24)}$. Briefly, using a $6 \mathrm{~mm}$ punch-biopsy (Acu-punch, Acuderm, Inc., Fort Launderdale, FL, USA) tissue explants were obtained from the oral mucosa lining the inner cheek of the oral cavity, in close proximity to the lip, from three healthy, non-smoking volunteers, with no history of drug intake in the past 6 months ( 2 females and 1 male, mean ages $22 \pm 1$ years). Informed consent was obtained from the subjects, and the surgical protocol was approved by the Ethics Committee of The University of Concepción. Cells were cultured in Dulbecco's modified Eagle's medium (DMEM, GibcoBRL, Carlsbad, CA) supplemented with $10 \%$ fetal bovine serum (FBS, Gibco-BRL), $100 \mu \mathrm{g} / \mathrm{ml}$ penicillin/streptomycin (Gibco-BRL), $100 \mu \mathrm{g} / \mathrm{ml}$ fungizone (US Biological, Swampscott, MA) and $50 \mu \mathrm{g} / \mathrm{ml}$ of gentamycin (Sigma, St. Louis, MO) at $37^{\circ} \mathrm{C}$ in a $5 \% \mathrm{CO}_{2}$ atmosphere. All the assays were performed using fibroblasts between passages 4 and 10. HOM

1. Departamento de Estomatología Quirúrgica y Laboratorio de Biología y Patología Oral. Facultad de Odontología, Universidad de Concepción. Concepción, Chile.

2. Programa de Magíster en Ciencias Odontológicas, Mención Patología. Escuela de Graduados, Facultad de Odontología, Universidad de Chile. Santiago, Chile.

3. Unidad Académica Odontología. Facultad de Medicina, Pontificia Universidad Católica de Chile. Santiago, Chile.

4. Department of Pathology. College of Medicine, The Ohio State University. Columbus, Ohio, USA. 
fibroblast cultures were characterized by immunocytochemistry to confirm their phenotype with primary antibodies against vimentin (1:100) (Sigma, St Louis, MO, USA) and prolyl-4-hydroxylase (1:50) (Dako, Carpinteria, CA) followed by a secondary antibody coupled to an HRP detection system (Chemicon Int, Temecula, CA) and DAB as the chromogen (Vector Labs, Burlingame, CA).

\section{Growth Synchronization and UVB Light Exposure of HOM Fibroblasts}

Previous to UVB exposure, HOM fibroblasts were plated and maintained either in complete medium supplemented with $10 \%$ FBS for $12 \mathrm{hrs}$ (unsynchronized cells) or synchronized according to the protocol by Gilroy et al. $(2001)^{(25)}$. Briefly, cells were washed with PBS, plated in 96-well or $100 \mathrm{~mm}$ plates, and then incubated in serum-free medium for $24 \mathrm{hrs}$, followed by medium containing $2.5 \%$ FBS for $20 \mathrm{hrs}$. Previous to irradiation medium was replaced by $100 \mu \mathrm{l}$ of PBS (Gibco) in each well, or $10 \mathrm{ml}$ of PBS in the $100 \mathrm{~mm}$ plates. Then fibroblasts were irradiated with 30 or $60 \mathrm{~mJ} / \mathrm{cm}^{2}$ of UVB, equivalent to 2 and 4 minimal erythemal doses (MEDs) respectively, with Phillips FS40UVB lamps (American Ultraviolet Company, Murray Hill, NJ) as previously described ${ }^{(26)}$. Lamps were fitted with Kodacel filters (Eastman Kodak, Rochester, NY) to ensure emission of UVB light only (290-320). The intensity of the UVB light at the bottom of each well or plate was measured with a UVX Digital radiometer (UVP, Upland, CA, USA). Control fibroblasts were sham-irradiated.

\section{Cell Proliferation Assays}

To assess HOM fibroblast proliferation with the $\left[{ }^{3} \mathrm{H}\right]$-thymidine incorporation assay, fibroblasts were cultured in 96-well plates, at a density of $0.6-1 \times 10^{4} \mathrm{cells} / \mathrm{ml}$. Cells were UVB-irradiated and $0.5 \mu \mathrm{Ci}$ $\left[{ }^{3} \mathrm{H}\right]$-thymidine (specific activity, $50 \mathrm{Ci} / \mathrm{mmol}$, Dupont-NEN, Boston, MA) was added to the culture medium for 3 to $48 \mathrm{hrs}$. After incubation, cells were trypsinised, vacuumed onto paper filters $(45 \mu \mathrm{m}$ pores $)$ and placed in $5 \mathrm{ml}$ of scintillation fluid (Ecoscint LS-271, National Diagnostics, USA). The incorporated radioactivity was quantified by a scintillation counter (Packard 1600 TR, Packard Instruments, Downers Grove, IL, USA). Results were expressed as cpm/well.

For MTT proliferation assay, fibroblasts were cultured in 96well plates, at a density of $1 \times 10^{4}$ cells/ml. At 6,12 and 24 hrs post-UVB irradiation, $10 \mu \mathrm{l}$ of MTT solution were added to each well, and processed according to the manufacturer's instructions. Absorbance was measured at $570 \mathrm{~nm}$ using a microplate reader (Multiskan EX, Thermo Corporation, USA). In addition, cell viability was determined at 24 and 48 hrs posttreatment by trypan blue exclusion assay as previously described ${ }^{(27)}$. Experiments were repeated at least three times with 5-8 wells/group.

\section{Reverse Transcription-Polymerase Chain Reaction (RT-PCR)}

Total RNA was isolated from fibroblasts seeded onto 100 $\mathrm{mm}$ plates $\left(0.6 \times 10^{6}\right.$ cells/plate) with Trizol (Invitrogen, Rockville, MD), according to manufacturer's instructions ( $n=6-7$ plates/group at each time-point). RNA concentration and nucleic acid purity was determined spectrophotometrically by UV absorbance. RT-PCR for COX-2 and GAPDH was performed as previously described ${ }^{(5)}$. Briefly, $10 \mu \mathrm{g}$ of total RNA was reversed transcribed using oligo-dT primers and AMV reverse transcriptase (Promega, Madison $\mathrm{WI}$ ) and $1 \mu \mathrm{l}$ of cDNA from each sample was amplified by PCR. Each PCR was carried out in $25 \mu \mathrm{l}$ of a reaction mix containing $10 \mathrm{mM}$ Tris- $\mathrm{HCl}, 50 \mathrm{mM} \mathrm{KCl}, 3 \mathrm{mM} \mathrm{MgCl}$, $0.2 \mathrm{mM}$ of each dNTP, $0.4 \mu \mathrm{M}$ of each sense and antisense primer and one unit of Plantinum Taq DNA polymerase (Invitrogen, Carlsbad, CA). A negative control, where the cDNA was omitted from the reaction mix was run for each amplified gene. The following primer sequences were used: COX-2 sense 5'-GGT CTG GTG CCT GGT CTG ATG ATG-3' and antisense 5'-GTC CTT TCA AGG AGA ATG GTG C-3', product size 724 $\mathrm{bp}^{(28)}$ and GAPDH sense $5^{\prime}$-CGG AGT CAA CGG ATT TGG TCG TAT-3' and antisense 5'-GCC TTC TCC ATG GTT GGT GAA GAC-3', product size $301 \mathrm{bp}^{(29)}$. The reaction mixture was incubated for 1 minute at $94^{\circ} \mathrm{C}$, amplified for 35 PCR cycles and ended by incubation at $72^{\circ} \mathrm{C}$ for 10 minutes. Each PCR cycle consisted of denaturing for 45 seconds at $94^{\circ} \mathrm{C}$, annealing for 45 seconds at $60^{\circ} \mathrm{C}$, and extending for 2 minutes at $72^{\circ} \mathrm{C}$. Amplified samples were visualized after electrophoresis on $1.5 \%$ agarose gels and staining with ethidium bromide, with a gel photodocumentation system (Vilber Lourmat, Marne La Vallee, France). Band densitometry was performed with Image J Program (Bethesda, MD).

\section{Prostagandin $\mathrm{E}_{2}$ Assay}

HOM Fibroblasts, plated in $100 \mathrm{~mm}$ plates, were synchronized and UVB irradiated. At 12 and 24 hrs after irradiation, supernatants were collected and the amount of $\mathrm{PGE}_{2}$ secreted was determined by enzymelinked immunosorbent assay according to manufacturer's instructions (Cayman Chemical, Ann Arbor, MI, USA). Results were expressed as mean $\pm \mathrm{SD}$ of the percentage of $\mathrm{PGE}_{2}$ production $(\mathrm{pg} / \mathrm{ml})$ as compared to control.

\section{Statistical Analyses}

Statistical tests were performed using JMP-IN 4.0.4 (SAS Institute Inc., Cary, NC, USA). Differences between groups were examined using Mann-Whitney or t-test, according to data distribution. Differences were considered statistically significant when $p<0.05$.

\section{RESULTS}

Effects of UVB on Proliferation of Fibroblasts Derived from Human Oral Mucosa

Primary fibroblast cultures were obtained from human oral mucosa explants and characterized by immunocytochemistry. Greater than $95 \%$ of the cells stained positive for vimentin and prolyl-4-hydroxylase (Figure 1).

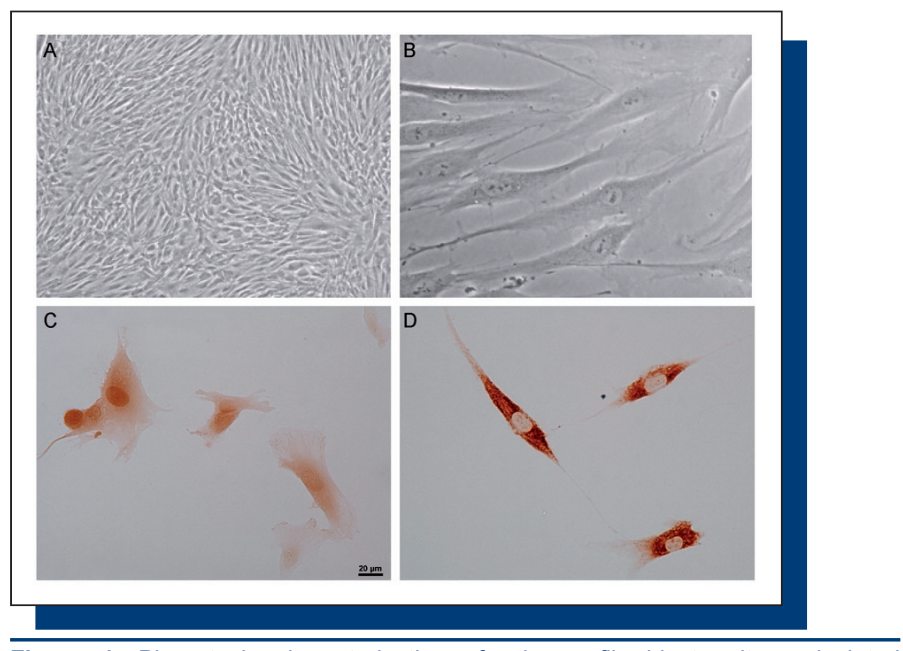

Figure 1. Phenotypic characterization of primary fibroblast cultures isolated from human oral mucosa (HOM). Phase-contrast microscopy of plated HOM fibroblasts (A and B) and immunodetection of vimentin (C) and prolyl-4hydroxylase (D) expression in HOM fibroblasts.

After 12 hrs of cell plating in 96-well plates at a density of 0.6 $x 10^{4}$ cells/well, growth medium was replaced by a thin layer of PBS and HOM fibroblasts were subjected to 30 or $60 \mathrm{~mJ} / \mathrm{cm}^{2}$ of UVB light or sham-irradiation. Proliferation was assessed from 3 to $48 \mathrm{hrs}$ after UVB irradiation with the $\left[{ }^{3} \mathrm{H}\right]$-thymidine incorporation assay. Analysis of the results showed that UVB irradiation, at both 30 and $60 \mathrm{~mJ} / \mathrm{cm}^{2}$, caused a significant decrease in HOM fibroblast proliferation from 6 to $48 \mathrm{hrs}$ after UVB irradiation ( $p<0.05$, ANOVA \& Tukey-Kramer tests) (Figure 2). Analysis of cell viability by trypan blue exclusion assay showed no increase in cell death (more than 95\% cell viability) at 24 and 48 hrs after UVB exposure with 30 and $60 \mathrm{~mJ} / \mathrm{cm}^{2}$ (data not shown). Therefore, the $60 \mathrm{~mJ} / \mathrm{cm}^{2}$ dose of UVB irradiation was used in the subsequent experiments. 


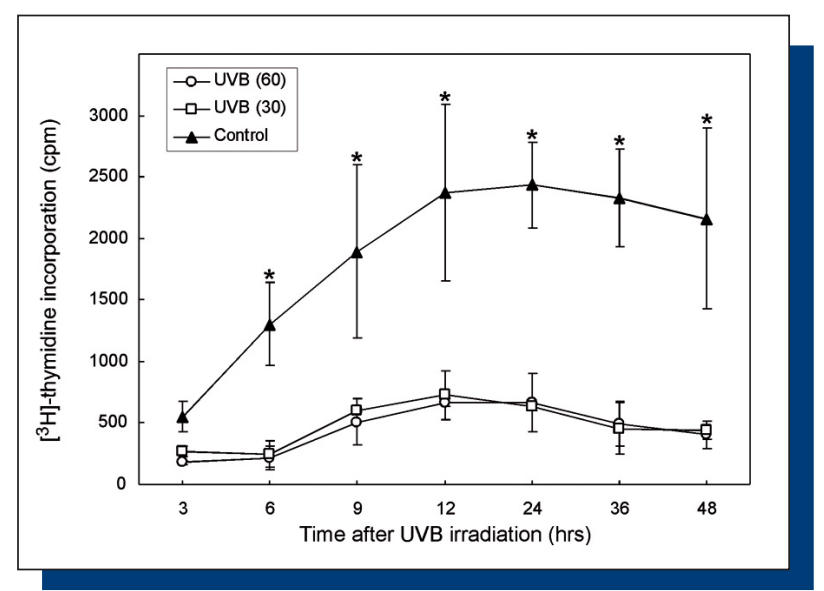

Figure 2. Effect of a single dose of UVB radiation on proliferation of HOM fibroblasts. Cells grown at a density of $0.6 \times 10^{4}$ cells/well for $12 \mathrm{hrs}$, were exposed to one single dose of 30 or $60 \mathrm{~mJ} / \mathrm{cm}^{2}$ of UVB, and proliferation was assessed from 3 to 48 hrs after UVB -or sham-irradiation (control) with $\left[{ }^{3} \mathrm{H}\right]$-thymidine incorporation assay. Results are expressed as mean \pm SD of one representative experiment $(n=8$ wells $/$ group) of at least 5 independent experiments.

${ }^{*} \mathrm{p}<0.05$ (ANOVA and Tukey Kramer test) for sham-irradiated HOM fibroblasts as compared to UVB-irradiated fibroblasts $\left(30\right.$ and $\left.60 \mathrm{~mJ} / \mathrm{cm}^{2}\right)$.

The effects of UVB on HOM proliferation was also assessed on previously synchronized fibroblasts using both $\left[{ }^{3} \mathrm{H}\right]$-thymidine incorporation and MTT assays, at 6,12 and $24 \mathrm{hrs}$ after UVB irradiation with $60 \mathrm{~mJ} / \mathrm{cm}^{2}$. Similar to non-synchronized cells, a significant decrease in proliferation of UVB-irradiated HOM fibroblasts was observed at all the time points analyzed as compared to sham-irradiated fibroblasts, with both assays ( $p<0.05$, t-test and Mann Whitney) (Figure 3 ).

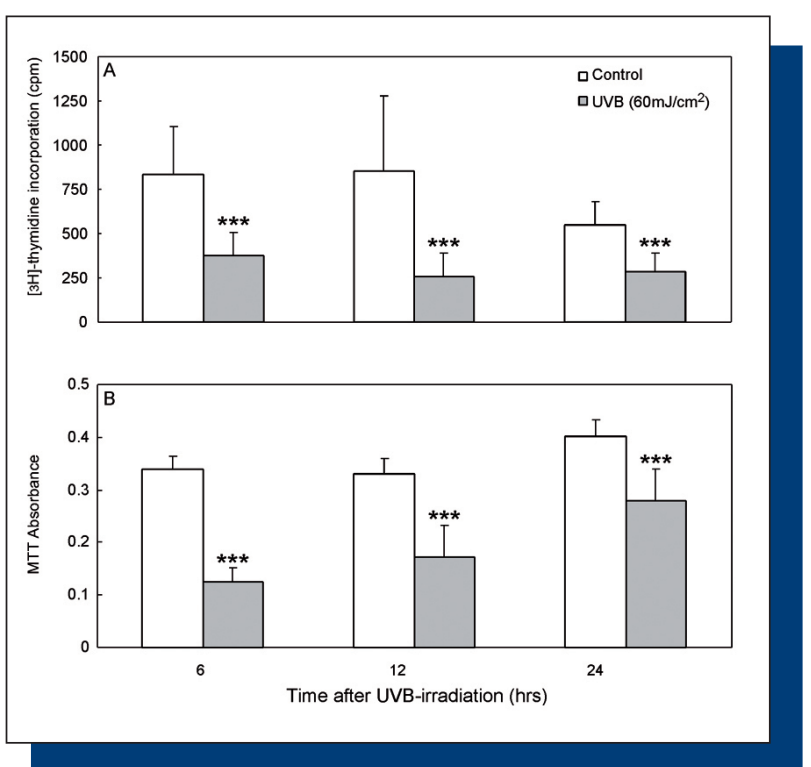

Figure 3. Effect of a single dose of UVB radiation on proliferation of synchronized HOM fibroblasts. Cells grown at a density of $1 \times 10^{4}$ cells/well, were synchronized in their cell cycle and exposed to one single dose of $60 \mathrm{~mJ} / \mathrm{cm}^{2}$ of UVB. Proliferation was assessed at 6,12 and $24 \mathrm{hrs}$ after UVB exposure or sham-irradiation (control) with $\left.{ }^{3} \mathrm{H}\right]$-thymidine incorporation $(\mathbf{A})$ and MTT $(\mathbf{B})$ assays. Results are expressed as mean $\pm \mathrm{SD}$ of one representative experiment repeated at least three times with similar results ( $n=8$ wells/group at each time point).

A) ${ }^{* *} \mathrm{p}<0.001$ (Mann Whitney) for UVB-irradiated fibroblasts as compared to controls at 6 hrs. ${ }^{* * *} \mathrm{p}<0.0001$ (t-test) for UVB-irradiated fibroblasts as compared to controls at 12 and $24 \mathrm{hrs}$.

B) ${ }^{* *} p<0.001$ (t-test and Mann Whitney) for UVB-irradiated fibroblasts as compared to controls at 6,12 and $24 \mathrm{hrs}$.
Effects of UVB Irradiation on COX-2 mRNA Expression by Synchronized HOM Fibroblasts

To assess COX-2 at the mRNA level, HOM fibroblasts were synchronized in their cell cycle in order to avoid changes in COX-2 expression that were not related to UVB radiation, as previously described ${ }^{(25)}$. Total RNA was subsequently extracted at $0.5,6,12$ and 24 hrs after UVB irradiation $\left(60 \mathrm{~mJ} / \mathrm{cm}^{2}\right)$ and subjected to RT-PCR. Samples were visualized in agarose gels stained with ethidium bromide (Figure $4 \mathrm{~A}$ ) and analyzed by densitometry. Analysis of densitometric units of COX-2 bands normalized to GAPDH showed a significant increase in the percentage of relative COX-2 mRNA expression at $30 \mathrm{~min}$ and $12 \mathrm{hrs}$ after UVB irradiation as compared to sham-irradiated controls $(p<0.05$, t-test) (Figure 4B).

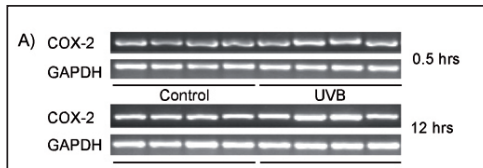

B

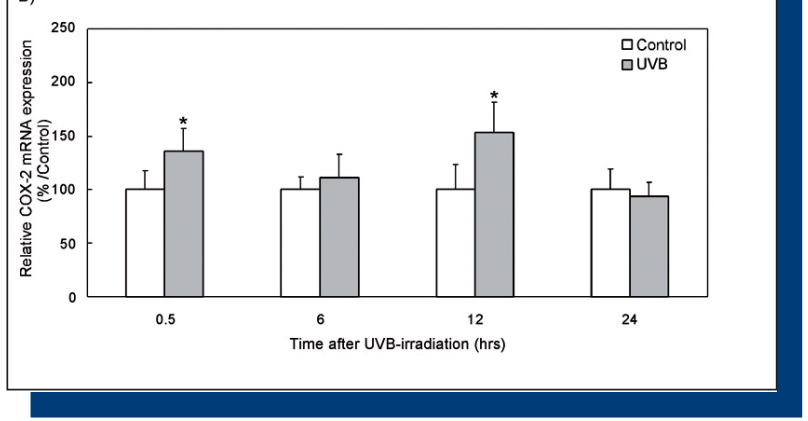

Figure 4. Effect of a single dose of UVB radiation on COX-2 mRNA expression by synchronized HOM fibroblasts. Total RNA was extracted from UVB -and shamirradiated (control) HOM fibroblasts $\left(6 \times 10^{5}\right.$ cells/plate) and subjected to RT-PCR to assess COX-2 (724 bp) and GAPDH (301 bp) mRNA expression. Products were visualized in $1.5 \%$ agarose gels stained with ethidium bromide. Representative gels of one of the experiments for 0.5 and 12 hrs after UVB irradiation are shown in (A). Relative densitometric units of COX-2 bands (normalized to GAPDH) were calculated. Results are expressed in percentage of corresponding control as mean \pm SEM of two pooled experiments ( $n=7$ plates/group at 0.5 and $12 \mathrm{hrs}, n=6$ plates/ group at 6 and $24 \mathrm{hrs})(\mathrm{B})$.

${ }^{*} p<0.05$ (t-test) for UVB-irradiated fibroblasts as compared to controls at 0.5 and 12 hrs after UVB exposure.

\section{Effects of UVB on $\mathrm{PGE}_{2}$ Production by Synchronized HOM Fibroblasts}

$\mathrm{PGE}_{2}$ production was measured by EIA from the supernatants of synchronized HOM fibroblasts at 12 and $24 \mathrm{hrs}$ after UVB irradiation. The results showed a significant increase in $\mathrm{PGE}_{2}$ production by HOM fibroblasts at both 12 and 24 hrs after UVB irradiation as compared to controls $(p<0.05$ and $p<0.01$ respectively, Mann Whitney) (Figure 5). 


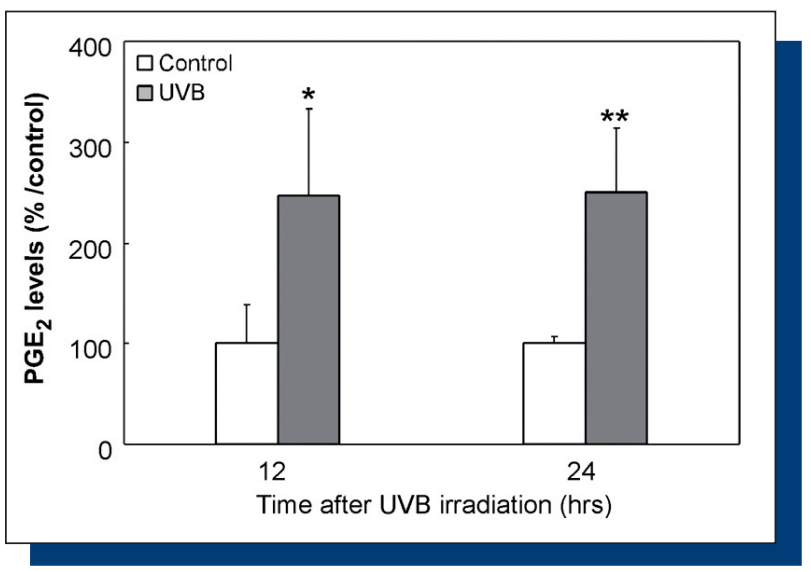

Figure 5. Effect of a single dose of UVB radiation on $\mathrm{PGE}_{2}$ production by synchronized HOM fibroblasts. PGE levels (pg/ml) were assessed by EIA at 12 and $24 \mathrm{hrs}$ after UVB irradiation from supernatants of synchronized HOM fibroblasts (6 $\times 10^{5} \mathrm{cells} /$ plate). Results are expressed in percentage of corresponding control as mean \pm SEM of two pooled experiments ( $n=7$ plates/group at $12 \mathrm{hrs}$ and $n=6$ plates/ group at $24 \mathrm{hrs}$ ).

${ }^{*} p<0.05$ and ${ }^{* *} p<0.01$ (Mann Whitney) for UVB-irradiated fibroblasts as compared to sham-irradiated at 12 and $24 \mathrm{hrs}$ after UVB exposure, respectively.

\section{DISCUSSION}

The results of this in vitro study showed that exposure of $\mathrm{HOM}$ fibroblasts to a single subcytotoxic dose of UVB light $\left(60 \mathrm{~mJ} / \mathrm{cm}^{2}\right)$ significantly reduced cell proliferation during the first $48 \mathrm{hrs}$ after UVB exposure as assessed by $\left[{ }^{3} \mathrm{H}\right]$-thymidine incorporation and MTT assays. UVB-irradiated HOM fibroblasts also had increased COX-2 mRNA expression at 0.5 and $12 \mathrm{hrs}$ after UVB exposure and enhanced COX-2 activity, as reflected by an increase in $\mathrm{PGE}_{2}$ production at 12 and $24 \mathrm{hrs}$ after irradiation.

Very few studies have assessed the effects of UV light on proliferation of fibroblasts from the oral cavity ${ }^{(18)}$. Williams et al. (1992) showed that UVA light, with exposure times ranging from 15 seconds to 14 minutes, significantly decreased $\left[{ }^{3} \mathrm{H}\right]$-thymidine incorporation by gingival fibroblasts ${ }^{(18)}$. On the other hand, the effects of UVB light on proliferation of both, lung mucosa and skin fibroblasts are well known ${ }^{(30-32)}$. Straface et al. (2007) found that early exposure of lung mucosa fibroblasts (passages 2-4) to a single subcytotoxic dose of UVB $\left(200 \mathrm{~mJ} / \mathrm{cm}^{2}\right)$ resulted in a significant decrease in cell proliferation, similar to non-irradiated lung fibroblasts from later passages (greater than 11 passages) ${ }^{(30)}$. Chainiaux et al. (2002) using human diploid skin fibroblasts exposed to repeated subcytotoxic UVB doses $\left(62.5 \mathrm{~mJ} / \mathrm{cm}^{2}\right)$ also found decreased proliferation, as assessed by $\left[{ }^{3} \mathrm{H}\right]$-thymidine incorporation ${ }^{(31)}$. Therefore, UVB irradiation had a similar inhibitory effect on oral mucosa fibroblast proliferation as previously shown for skin and lung fibroblasts.

Since the MTT assay allows determination of both, cell proliferation and cytotoxicity ${ }^{(33)}$, the results may also suggest that the proliferation inhibition in HOM fibroblasts irradiated with $60 \mathrm{~mJ} / \mathrm{cm}^{2}$ was due to reduced cell viability. Previously, mild to moderate cell cytotoxicity was described for skin fibroblasts at $24 \mathrm{hrs}$ after irradiation with UVB doses of 40 and $60 \mathrm{~mJ} / \mathrm{cm}^{2(32)}$. However, in this study, no increase in cell death was found, as assessed by trypan blue exclusion assay, at 24 and $48 \mathrm{hrs}$ after UVB irradiation (more than 95\% viability), suggesting higher resistance of oral mucosa fibroblasts to UVB exposure as compared to skin fibroblasts.

Increased COX-2 expression has been described for UVBirradiated skin fibroblasts ${ }^{(15)}$. It has been shown that transcriptional control of COX-2 is associated with: the proliferation status of fibroblasts. COX-2 up-regulation was observed in quiescent cells, whereas COX-2 down- regulation was found in proliferating fibroblasts ${ }^{(25,34)}$. In a similar way, UVB-irradiated oral mucosa fibroblasts, which presented an inhibition of their proliferative response, also had and increase in COX-2 expression and activation. Therefore, the inhibition of fibroblast proliferation by UVB irradiation may have both, a protective effect by reducing expansion of photodamaged fibroblasts and, on the other hand, a procarcinogenic effect by increasing COX-2 expression and activation.

In the last decade, fibroblasts have emerged as crucial regulators of epithelial and endothelial cell function, as well as, ECM composition ${ }^{(35)}$. During carcinogenesis, stromal fibroblasts undergo several changes that range from an activated to a myofibroblast phenotype. These changes are

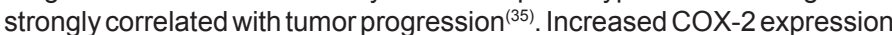
by stromal fibroblasts has been described in laryngeal, lung and colon carcinogenesis with a direct association with prognosis ${ }^{(36-38)}$. Several carcinogens increase COX-2 expression in oral mucosa fibroblasts, including nicotine and areca nut extract ${ }^{(20,22)}$. The present study showed that UVB radiation, which is a complete carcinogen, also induces COX-2 expression and activation in oral mucosa fibroblasts. Future work should focus on elucidating the signal transcription pathways that participate in UVB-induced COX-2 upregulation in oral mucosa fibroblasts, which may involve NF- $\kappa$ B activation as has already been described for UVBirradiated skin fibroblasts, and nicotine-treated gingival fibroblasts ${ }^{(15,21)}$

Previous studies describing COX-2 overexpression at the epithelium of photodamaged lips ${ }^{(5)}$, as well as, the present results showing increased COX-2 expression in UVB-irradiated HOM fibroblasts, strongly suggest that COX-2 modulation may be of clinical significance for prevention and treatment of lip carcinogenesis. It has been already shown that selective COX-2 inhibitors, such as Celecoxib, are effective in reducing UVB-induced chronic inflammation and tumor formation in the $\operatorname{skin}^{(26,39)}$. Epidemiological studies have shown that lip cancer has a higher metastasis occurrence than skin cancer ${ }^{(40)}$, which may be due to phenotypic differences between epithelial and stromal cells from skin and lip tissues ${ }^{(11,12)}$. Future studies should continue to investigate the role of fibroblasts and their interactions with stromal cells during lip photodamage and carcinogenesis, as well as, the therapeutic benefit of modulating fibroblast function and phenotype in the treatment of premalignant and malignant lesions of the lip.

\section{CONFLICT OF INTEREST STATEMENT}

None declared.

\section{ACKNOWLEDGMENTS}

This research was supported by the Chilean Council for Science and Technology CONICYT, grants FONDECYT 1090287, 1050581, and 7050210 (International collaboration grant). Dr. Yadira Boza wishes to thank the government of Costa Rica for financing her graduate studies. 


\section{REFERENCES}

1. Lundeen RC, Langlais RP, Terezhalmy GT. Sunscreen protection for lip mucosa: a review and update. J Am Dent Assoc, 1985; 111: 617-621.

2. Kaugars GE, Pillion T, Svirsky JA, Page DG, Burns JC, Abbey LM. Actinic cheilitis: a review of 152 cases. Oral Surg Oral Med Oral Pathol Oral Radiol Endod, 1999; 88: 181-186.

3. Rundhaug JE, Fischer SM. Cyclo-oxygenase-2 plays a critical role in UV-induced skin carcinogenesis. Photochem Photobiol, 2008; 84: 322329.

4. Yaar M, Gilchrest BA. Photoageing: mechanism, prevention and therapy. Br J Dermatol, 2007; 157: 874-887.

5. Rojas IG, Martínez A, Brethauer U et al. Actinic cheilitis: epithelial expression of COX-2 and its association with mast cell tryptase and PAR-2. Oral Oncol, 2009; 45: 284-290.

6. Martínez A, Brethauer U, Borlando J, Spencer ML, Rojas IG. Epithelial expression of p53, mdm-2 and p21 in normal lip and actinic cheilitis. Oral Oncol, 2008; 44: 878-883.

7. Neto Pimentel DR, Michalany N, Alchorne M, Abreu M, Borra RC, Weckx L. Actinic cheilitis: histopathology and p53. J Cutan Pathol, 2006; 33: 539-544.

8. Rosette C, Karin M. Ultraviolet light and osmotic stress: activation of the JNK cascade through multiple growth factor and cytokine receptors. Science, 1996; 274: 1194-1197.

9. Clydesdale GJ, Dandie GW, Muller HK. Ultraviolet light induced injury: immunological and inflammatory effects. Immunol Cell Biol, 2001; 79: 547-568.

10. Yokoo S, Yamagami S, Mimura T et al. UV absorption in human oral mucosal epithelial sheets for ocular surface reconstruction. Ophthalmic Res, 2006; 38: 350-354.

11. McKeown ST, Barnes JJ, Hyland PL, Lundy FT, Fray MJ, Irwin CR. Matrix metalloproteinase- 3 differences in oral and skin fibroblasts. J Dent Res, 2007; 86: 457-462.

12. Stephens $\mathrm{P}$, Davies KJ, Occleston $\mathrm{N}$ et al. Skin and oral fibroblasts exhibit phenotypic differences in extracellular matrix reorganization and matrix metalloproteinase activity. Br J Dermatol, 2001; 144: 229-237.

13. Chen W, Kang J, Xia J et al. p53-related apoptosis resistance and tumor suppression activity in UVB-induced premature senescent human skin fibroblasts. Int J Mol Med, 2008; 21: 645-653.

14. Debacq-Chainiaux F, Borlon C, Pascal T et al. Repeated exposure of human skin fibroblasts to UVB at subcytotoxic level triggers premature senescence through the TGF-beta1 signaling pathway. J Cell Sci, 2005; 118: 743-758.

15. Marwaha $\mathrm{V}$, Chen $\mathrm{YH}$, Helms $\mathrm{E}$ et al. T-oligo treatment decreases constitutive and UVB-induced COX-2 levels through p53- and NFkappaBdependent repression of the COX-2 promoter. J Biol Chem, 2005; 280: 32379-32388.

16. Tober KL, Wilgus TA, Kusewitt DF, Thomas-Ahner JM, Maruyama T, Oberyszyn TM. Importance of the EP(1) receptor in cutaneous UVBinduced inflammation and tumor development. $J$ Invest Dermatol, 2006; 126: 205-211.

17. Oberyszyn TM. Non-melanoma skin cancer: importance of gender, immunosuppressive status and vitamin D. Cancer Lett, 2008; 261: $127-$ 136.

18. Williams JK, Davidson SF, Johnson SG, Hsu HS, Das SK. An in vitro study on the effect of UVA radiation on human gingival fibroblasts. $\mathrm{Br} J$ Plast Surg, 1992; 45: 349-353.

19. Lim W, Ko M, Lee S et al. Ultraviolet-C-induced apoptosis protected by 635 -nm laser irradiation in human gingival fibroblasts. Photomed Laser Surg, 2008; 26: 215-220.

20. Chang YC, Tsai $\mathrm{CH}$, Yang SH, Liu CM, Chou MY. Induction of cyclooxygenase-2 mRNA and protein expression in human gingival fibroblasts stimulated with nicotine. J Periodontal Res, 2003; 38: 496501.

21. Nakao S, Ogata Y, Sugiya H. Nicotine stimulates the expression of cyclooxygenase-2 mRNA via NFkappaB activation in human gingival fibroblasts. Arch Oral Biol, 2009; 54: 251-257.

22. Tsai $\mathrm{CH}$, Chou MY, Chang YC. The up-regulation of cyclooxygenase-2 expression in human buccal mucosal fibroblasts by arecoline: a possible role in the pathogenesis of oral submucous fibrosis. J Oral Pathol Med, 2003; 32: 146-153.
23. Yucel-Lindberg T, Ahola $\mathrm{H}$, Nilsson $\mathrm{S}$, Carlstedt-Duke J, Modéer T. Interleukin-1 beta induces expression of cyclooxygenase-2 mRNA in human gingival fibroblasts. Inflammation, 1995; 19: 549-560.

24. Larvaja H, Heino J, Kahari V, Krusius T, Vuorio E. Characterization of one phenotype of human periodontal granulation-tissue fibroblasts. $J$ Dent Res, 1989; 68: 20-25.

25. Gilroy DW, Saunders MA, Sansores-Garcia L, Matijevic-Aleksic N, Wu KK. Cell cycle-dependent expression of cyclooxygenase-2 in human fibroblasts. FASEB J, 2001; 15: 288-290.

26. Wilgus TA, Koki AT, Zweifel BS, Rubal PA, Oberyszyn TM. Chemotherapeutic efficacy of topical celecoxib in a murine model of ultraviolet light B-induced skin cancer. Mol Carcinog, 2003; 38: 33-39.

27. Rudolph MI, Boza Y, Yefi R et al. The influence of mast cell mediators on migration of SW756 cervical carcinoma cells. J Pharmacol Sci, 2008; 106: 208-218.

28. Chan G, Boyle JO, Yang EK et al. Cyclooxygenase-2 expression is up-regulated in squamous cell carcinoma of the head and neck. Cancer Res, 1999; 59: 991-994.

29. Baram D, Vaday GG, Salamon P, Drucker I, Hershkoviz R, Mekori YA. Human mast cells release metalloproteinase- 9 on contact with activated T cells: juxtacrine regulation by TNF-alpha. J Immunol, 2001; 167: 40084016.

30. Straface E, Vona R, Ascione B et al. Single exposure of human fibroblasts (WI-38) to a sub-cytotoxic dose of UVB induces premature senescence. FEBS Lett, 2007; 581: 4342-4348.

31. Chainiaux F, Magalhaes JP, Eliaers F, Remacle J, Toussaint O. UVBinduced premature senescence of human diploid skin fibroblasts. Int $J$ Biochem Cell Biol, 2002; 34: 1331-1339.

32. Choi MS, Yoo MS, Son DJ et al. Increase of collagen synthesis by obovatol through stimulation of the TGF-beta signaling and inhibition of matrix metalloproteinase in UVB-irradiated human fibroblast. J Dermatol Sci, 2007; 46: 127-137.

33. Mosmann T. Rapid colorimetric assay for cellular growth and survival: application to proliferation and cytotoxicity assays. J Immunol Methods, 1983; 65: 55-63.

34. Wu KK. Differential cyclooxygenase-2 transcriptional control in proliferating versus quiescent fibroblasts. Prostaglandins Other Lipid Mediat, 2007; 83: 175-181.

35. Kalluri R, Zeisberg M. Fibroblasts in cancer. Nat Rev Cancer, 2006; 6: 392-401.

36. Charalambous MP, Lightfoot T, Speirs V, Horgan K, Gooderham NJ. Expression of COX-2, NF-kappaB-p65, NF-kappaB-p50 and IKKalpha in malignant and adjacent normal human colorectal tissue. $\mathrm{Br} \mathrm{J}$ Cancer, 2009; 101: 106-115.

37. Kourelis K, Vandoros G, Kourelis T, Papadas T, Goumas P, Sotiropoulou-Bonikou G. Low COX-2 in tumor and upregulation in stroma mark laryngeal squamous cell carcinoma progression. Laryngoscope, 2009; 119: 1723-1729.

38. Matsuzuka T, Miller K, Pickel L, Doi C, Ayuzawa R, Tamura M. The synergistic induction of cyclooxygenase- 2 in lung fibroblasts by angiotensin II and pro-inflammatory cytokines. Mol Cell Biochem, 2009; 320: 163-171.

39. Wilgus TA, Koki AT, Zweifel BS, Kusewitt DF, Rubal PA, Oberyszyn TM. Inhibition of cutaneous ultraviolet light B-mediated inflammation and tumor formation with topical celecoxib treatment. Mol Carcinog, 2003; 38: 49-58.

40. Vukadinovic M, Jezdic Z, Petrovic M, Medenica LM, Lens M. Surgical management of squamous cell carcinoma of the lip: analysis of a 10-year experience in 223 patients. J Oral Maxillofac Surg, 2007; 65: 675-679. 